\title{
Enhancing effect of modified beta-cyclodextrins on in vitro skin permeation of estradiol
}

\author{
Daniel De Paula', Dionéia Camilo Rodrigues Oliveira ${ }^{1}$, Antônio Cláudio Tedesco ${ }^{2}$, Maria Vitória \\ Lopes Badra Bentley,*
} ,', Departamento de Ciências Farmacêuticas, Faculdade de Ciências Farmacêuticas de Ribeirão Preto, Universidade
de São Paulo, ${ }^{2}$ Faculdade de Filosofia, Ciências e Letras de Ribeirão Preto, Universidade de São Paulo

*Correspondence:

M. V. L. B. Bentley

Departamento de Ciências

Farmacêuticas

Faculdade de Ciências

Farmacêuticas de Ribeirão Preto

Universidade de São Paulo

Av. do Café $s / n$

14040-903 - Ribeirão Preto - SP, Brazil

E-mail: vbentley@usp.br

\begin{abstract}
Estradiol, the most important hormone in females, was complexed with hydroxypropyl- $\beta$-cyclodextrin $(H P-\beta-C D)$ and randomly methylated $\beta$-cyclodextrin (RM- $\beta-C D)$. After obtaining the inclusion complexes, they were characterized by DSC, ${ }^{1} H-N M R$ and solubility studies. The enhancing effect of CDs on estradiol skin permeation/retention was investigated in vitro using Franz diffusion cells. Both CDs increased estradiol aqueous solubility, but in different proportions. DSC and NMR-H $H^{l}$ analyses showed that estradiol was complexed with both $C D s$ and $R M-\beta-C D$ has stronger interactions with the hormone than $H P-\beta-C D$. Moreover, complexes formation increased estradiol flux through the skin $(P<0.01)$, but the hormone retention in the stratum corneum (SC) only increased after complexation with $H P-\beta-C D$. On the other hand, only RM- $\beta-C D$ was able to modify estradiol retention in the $S C$ after skin pretreatment with CDs. The results suggest that the enhancing effect of CDs on estradiol flux through the skin may be mainly described as an increase in drug availability on the skin surface due to inclusion complexation. Furthermore, the formation of a significant reservoir of estradiol in the $S C$ due to $H P-\beta-C D$ complexation makes it an interesting approach for estradiol transdermal delivery.
\end{abstract}

Uniterms

- Estradiol

- Hydroxypropyl- $\beta$ cyclodextrin

- Methylated- $\beta$ cyclodextrin

- Inclusion complexation

- Skin permeation

- Absorption enhancer

\section{INTRODUCTION}

Estrogen replacement therapy has been used for postmenopausal symptoms prevention. Estradiol, the most important estrogen in females, is responsible for maintaining important physiological functions, such as bone mineral density, thyroid function, cardiovascular system health, mood, sexual function, skin elasticity and fertility (Miller, Franklin, 1999; Kenemans et al., 2001). Although the transdermal delivery of estradiol has shown more advantages over oral administration, such as sustained drug delivery, patient compliance improvement, side-effect reduction and elimination of first-pass effect (Essa, Bonner, Barry, 2004; Prausnitz, Mitragotri, Langer, 2004; Warming, 
Ravn Christiansen, 2005), the low aqueous solubility of estradiol makes the development of new transdermal delivery systems difficult.

In the pharmaceutical industry, cyclodextrins (CDs) have mainly been used as complexing agents to increase the aqueous solubility, availability, and stability of poorly watersoluble drugs. CDs are cyclic $(\alpha-1,4)$-linked oligosaccharides of $\alpha$-D-glucopyranose containing a relatively hydrophobic central cavity and a hydrophilic external surface. The most common CDs are $\alpha, \beta$ and $\gamma-\mathrm{CD}$, which consist of six, seven and eight glucopyranose units, respectively. In aqueous environment, $C D$ s are capable of forming inclusion complexes with many drugs by incorporating a whole drug molecule or at least some lipophilic moiety of a molecule into the cavity. The complexes are readily dissociated and free drug molecules are in relative equilibrium with drug molecules bound within the CD cavity (Stella et al., 1999; Del Valle, 2004; Loftsson, Hreinsdóttir, Másson, 2005).

The rate-limiting barrier to transdermal drug delivery is the outermost layer of skin, the stratum corneum (SC) (Hadgraft, 2004). Conventional absorption enhancers, such as alcohols and fatty acids, disrupt the lipid layers of biological barriers, generally inducing skin irritation (Williams, Barry, 2004). It has been demonstrated that some modified $\beta$-CDs such as methylated $\alpha-C D$ and hydroxypropyl- $\beta-\mathrm{CD}$ (HP- $\beta$-CD) are able to interact with lipophilic components of SC (Bentley et al., 1997; Loftsson, Másson, 2001) and improve drug absorption (Másson et al., 1999; Lopez, Collet, Bentley, 2000). Moreover, methylated $\beta$-CDs are known to extract several classes of lipids and therefore reduce the skin barrier, acting as true absorption enhancers (Vollmer et al., 1994; Matsuda, Arima, 1999; Babu, Pandit, 2004).

Thus, the present study reports the characterization of estradiol inclusion complexes formed with two modified CDs, HP- $\beta-\mathrm{CD}$ and randomly methylated- $\beta-\mathrm{CD}$ (RM- $\beta-$ $\mathrm{CD})$, in solution and in solid state. Furthermore, the influence of these CDs on the in vitro permeation/retention of estradiol through hairless mouse skin was investigated.

\section{MATERIAL AND METHODS}

\section{Material}

HP- $\beta$-CD was obtained from TRAPPSOL (Gainesville, Fl, USA). RM- $\beta$-CD and 17- $\beta$-estradiol (estra-1,3,5(10)-triene3,17ß-diol) were obtained from SIGMA (St. Louis, MO, USA). The degrees of substitution (number of substituted groups per $\beta-C D$ unit) were 4.4 and 1.7 for HP- $\beta-C D$ and RM- $\beta-C D$, respectively. All other reagents and salts were of analytical or HPLC grade and were used as received.

\section{Phase solubility studies}

According to Higuchi and Connors (1965), excess amounts of estradiol were added to aqueous solutions containing various concentrations of HP- $\beta-C D$ or $\mathrm{RM}-\beta-\mathrm{CD}$ (0 to $50.0 \mathrm{mM}$ ). Samples were maintained at $25^{\circ} \mathrm{C}$ and stirred $(300 \mathrm{rpm})$ for $24 \mathrm{~h}$. Afterwards, samples were filtered $(0.45 \mu \mathrm{m})$, appropriately diluted in methanol and analyzed at $280 \mathrm{~nm}$ using a HITACHI U-3501 spectrophotometer. The estradiol calibration curve was also done in methanol. Apparent 1:1 stability constants $\left(K_{c}\right)$ were determined from the initial straight-line portion of the phase solubility diagrams:

$$
K_{\mathrm{c}}=\frac{\text { Slope }}{S_{\mathrm{o}} \mathrm{x}(1-\text { Slope })}
$$

where $\left(S_{\mathrm{o}}\right)$ is the free estradiol aqueous solubility.

Solid complexes were obtained by lyophilization in order to carry out physical characterization. The complexes molar ratios were determined by UV measurements at $280 \mathrm{~nm}$. Each experiment was conducted in triplicate (coefficient of variation, $\mathrm{CV}<3 \%$ ).

\section{Differential scanning calorimetry measurements (DSC)}

DSC measurements were conducted on NETZSCH DSC 200 equipment. Each sample (solid inclusion complexes, physical mixtures in a same equimolar ratio and pure components) was weighed in open aluminum pans and scanned at a heating rate of $5{ }^{\circ} \mathrm{C} / \mathrm{min}$ in the temperature range between 25 and $250{ }^{\circ} \mathrm{C}$. Hydrogen was used as purging gas. Indium (99.9\%) was used as a standard for calibration of the DSC equipment.

\section{Nuclear magnetic resonance measurements ( ${ }^{1} \mathrm{H}-\mathrm{NMR}$ )}

${ }^{1} \mathrm{H}-\mathrm{NMR}$ was carried out using a BRUKER DPX spectrometer operating at $300 \mathrm{MHz}$. Samples (free estradiol and solid complexes) were dissolved in $\mathrm{D}_{2} 0$ :Deuterated methanol (1:1). Tetramethylsilane was used as internal reference with an accuracy of $\pm 0.001 \mathrm{ppm}$. The conditions for Fourier transform measurements were: acquisition time, $3.5 \mathrm{~s}$; pulse angle, $30^{\circ}$; delay time, $2 \mathrm{~s}$; number of spectra, 16 .

\section{Skin permeation studies}

The permeation studies were performed in modified Franz diffusion cells (Hanson Research) at $37^{\circ} \mathrm{C}$ during $24 \mathrm{~h}$. Full-thickness skin of male hairless mice HRS/J strain (4-6 weeks old), supplied by Jackson Laboratories (Bar Harbor, ME, USA), was clamped between the donor and the receptor phases with a diffusion area of $1.77 \mathrm{~cm}^{2}$. The receptor compartment was filled with $7.0 \mathrm{~mL}$ of phosphate buffer $(0.1 \mathrm{M}, \mathrm{pH} 7.2)$ containing $10 \%(\mathrm{v} / \mathrm{v})$ of ethanol in order to 
maintain sink conditions. PG:water (1:1) was used as vehicle in the donor phase. Saturated solution of free estradiol $(0.05 \%$, $\mathrm{w} / \mathrm{v}$ ) was used as a control group. Donor phases containing estradiol/CDs complexes were used in an equivalent concentration of $3.0 \%(\mathrm{w} / \mathrm{v})$ of CDs, corresponding to $0.18 \%$ $(\mathrm{w} / \mathrm{v})$ and $0.2 \%(\mathrm{w} / \mathrm{v})$ of estradiol for HPCD and RMCD complex, respectively. All experiments were conducted with saturated solutions of estradiol. Aliquots of $1.0 \mathrm{~mL}$ were withdrawn periodically and replaced with the same volume of receptor solution. After that, samples were extracted and analyzed by HPLC.

\section{Pretreatment studies}

In order to study the effect of HP- $\beta-C D$ and RM- $\beta-C D$ on the SC barrier, the skin was kept in the diffusion cells, as described previously, and treated with aqueous solution containing $20 \%$ (w/v) of HP- $\beta$-CD or RM- $\beta-C D$ in the donor phase during four hours. Aqueous solution with no $C D$ was used as control group. Then, the skin was washed carefully with distilled water in order to carry out permeation experiments using saturated solution of estradiol $(0.05 \%$, $\mathrm{w} / \mathrm{v})$ in PG:water (1:1) as donor phase.

\section{Skin retention studies}

After in vitro permeation experiments ( $24 \mathrm{~h})$, the skin was removed from diffusion cells and washed with water to remove formulation excess. SC exposed to formulations $\left(1.77 \mathrm{~cm}^{2}\right)$ was removed by stripping the skin 10 times with adhesive cellophane tapes. The adhesive tapes of each skin sample and the tape-stripped skin (epidermis plus dermis without SC) were homogenized in methanol and maintained in ultrasound bath for $30 \mathrm{~min}$ in order to extract the estradiol retained (Surber, Schwarb, Smith, 1999). Subsequently, samples were filtered $(0.45 \mu \mathrm{m})$ and the amount of estradiol was assayed by HPLC.

\section{Data analysis}

Permeation profiles of estradiol were constructed by plotting time (hours) against the cumulative amount of the drug $\left(\mu \mathrm{g} / \mathrm{cm}^{2}\right)$ measured in the receptor solution. The linear portion of estradiol permeation profiles, with a correlation coefficient greater than 0.90 , was considered indicative of steady state permeation and used for flux $(J)$ determination by linear regression, which was expressed as $\mu \mathrm{g} / \mathrm{cm}^{2} / \mathrm{h}$.

Permeation data were compared by ANOVA followed by Tukey's test to determine the level of significance between CDs and control groups. The data were considered to be significant at $P<0.05$.

\section{HPLC analysis}

The apparatus used for HPLC analysis was a Shimadzu
(Japan) system equipped with an LC-10AD pump and an SPD10A/10AV UV-Vis detector. Data acquisition was performed with an Intralab 4290 integrator. An LiChrospher $100 \mathrm{C}_{18}$ reverse-phase column $125 \times 4 \mathrm{~mm}(5 \mu \mathrm{m})$ and a $\mathrm{C}_{18}$ precolumn 4 x $4 \mathrm{~mm}(5 \mu \mathrm{m})$ from Merck (Darmstadt, Germany) were used. The detection wavelength was set at $280 \mathrm{~nm}$. The mobile phase used was acetonitrile:water (60:40) in a flow rate of $1 \mathrm{~mL} / \mathrm{min}$ (Russel et al., 2000). Samples were injected manually in a volume of $20 \mu \mathrm{L}$.

The estradiol contained in the receptor solution from permeation studies was extracted using $3 \mathrm{~mL}$ of chloroform. After extraction, the chloroform was evaporated and the remaining estradiol was redissolved in $100.0 \mu \mathrm{L}$ of mobile phase by vortexing the tubes for $1 \mathrm{~min}$. Desonide was used as internal standard $(200.0 \mathrm{ng} / \mathrm{mL})$. The retention times for desonide and estradiol were 3.9 and $7.2 \mathrm{~min}$, respectively. The method was linear at a concentration range from 50.0 to $1000.0 \mathrm{ng} / \mathrm{mL}$ of estradiol $(\mathrm{y}=5.465 \mathrm{x}+0.071, r=0.9993)$. The extraction procedure presented a recovery of $93.01 \%$.

\section{RESULTS AND DISCUSSION}

\section{Phase solubility studies}

Figure 1 shows the aqueous phase-solubility of estradiol at different concentrations of HP- $\beta-C D$ and RM$\beta$-CD. Estradiol solubility increased as a function of CDs concentration. Both complexes showed an $A_{L}$ type solubility curve, which indicates that estradiol solubility increases linearly with the increase of CD concentration, depending on the $\mathrm{CD}$ aqueous solubility (Higuchi, Connors, 1965; Loftsson, Hreinsdóttir, Másson, 2005).

According to Table I, the estradiol aqueous solubility in the presence of $50 \mathrm{mM}$ of CD increased 110- and 139fold when HP- $\beta-C D$ and RM- $\beta-C D$ were used, respectively. This difference in performance of CDs can be related to $K_{\mathrm{c}}$ values of the complexes, which is an empirical parameter that describes the increase in drug apparent solubility in the presence of CDs (Higuchi, Connors, 1965; Del Valle, 2004; Loftsson, Hreinsdóttir, Másson, 2005). Assuming that an 1:1 complex is initially formed, the RM- $\beta$-CD $K_{\mathrm{c}}$ value $\left(4.23 \times 10^{3} \mathrm{M}^{-1}\right)$ was greater than HP- $\beta$-CD $\left(3.06 \times 10^{3} \mathrm{M}^{-1}\right)$. It has been suggested that the spatial relationship between host and guest molecules (steric and hydrophobic factors) was responsible for their interaction (Higuchi, Connors, 1965; Loftsson, Brewster, 1996; Loftsson, Hreinsdóttir, Másson, $2005)$. Thus, $R M-\beta-C D$ solubilized estradiol better than HP- $\beta-C D$, probably due to its larger cavity size and higher hydrophobicity than that of HP- $\beta-C D$.

Additionally, the molar ratio of solid complexes was also 


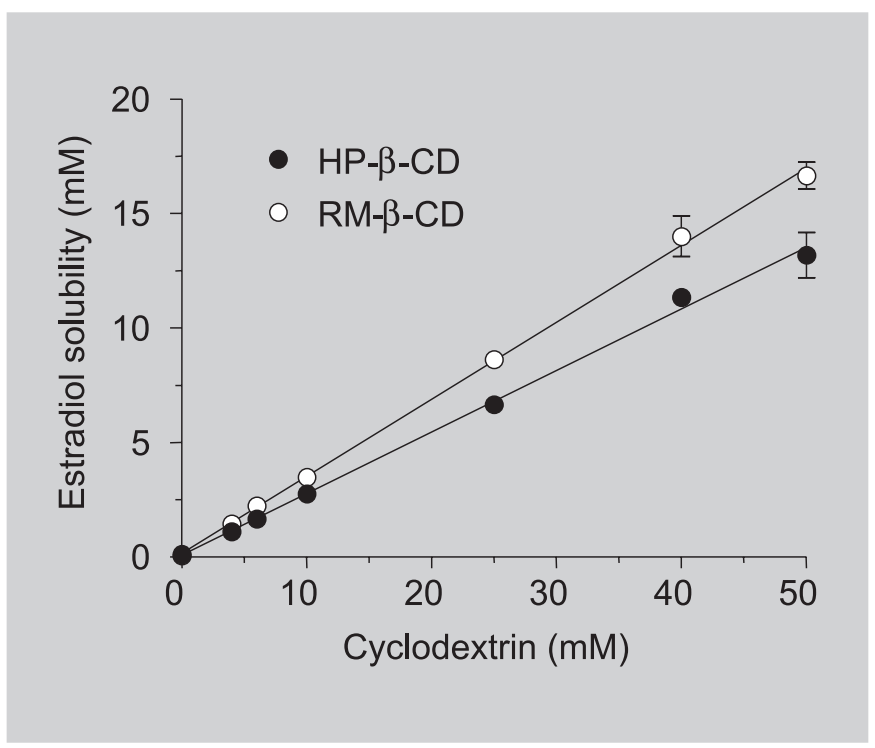

FIGURE 1 - Solubility diagram of estradiol in the presence of CDs. Values are expressed as mean \pm S.D $(n=3)$. calculated. The estradiol/HP- $\beta$-CD complex showed a molar ratio of $1: 3$ whereas only 2.4 moles of RM- $\beta$-CD was necessary to solubilize one mol of estradiol. The increase in estradiol solubility observed with both CDs may be attributed to complex formation, but it is not enough to state that estradiol is in the CDs cavity, since drug molecules could be interacting with the external surface of CDs. In this way, DSC and ${ }^{1} \mathrm{H}-$ NMR experiments were performed in order to verify estradiol inclusion complexation.

\section{Differential scanning calorimetry measurements (DSC)}

Thermal analyses have been described as a method to characterize interactions between drug and CDs molecules in solid state (Pralhad, Rajendrakumar, 2004; Mura et al., 2005). DSC profiles of estradiol, CDs, physical mixtures, and complexes are illustrated in Figure 2. In the estradiol thermogram, a sharp endothermic transition at $182.6^{\circ} \mathrm{C}$ was observed, corresponding to its melting point. The thermogram of HP- $\beta-\mathrm{CD}$ exhibited a

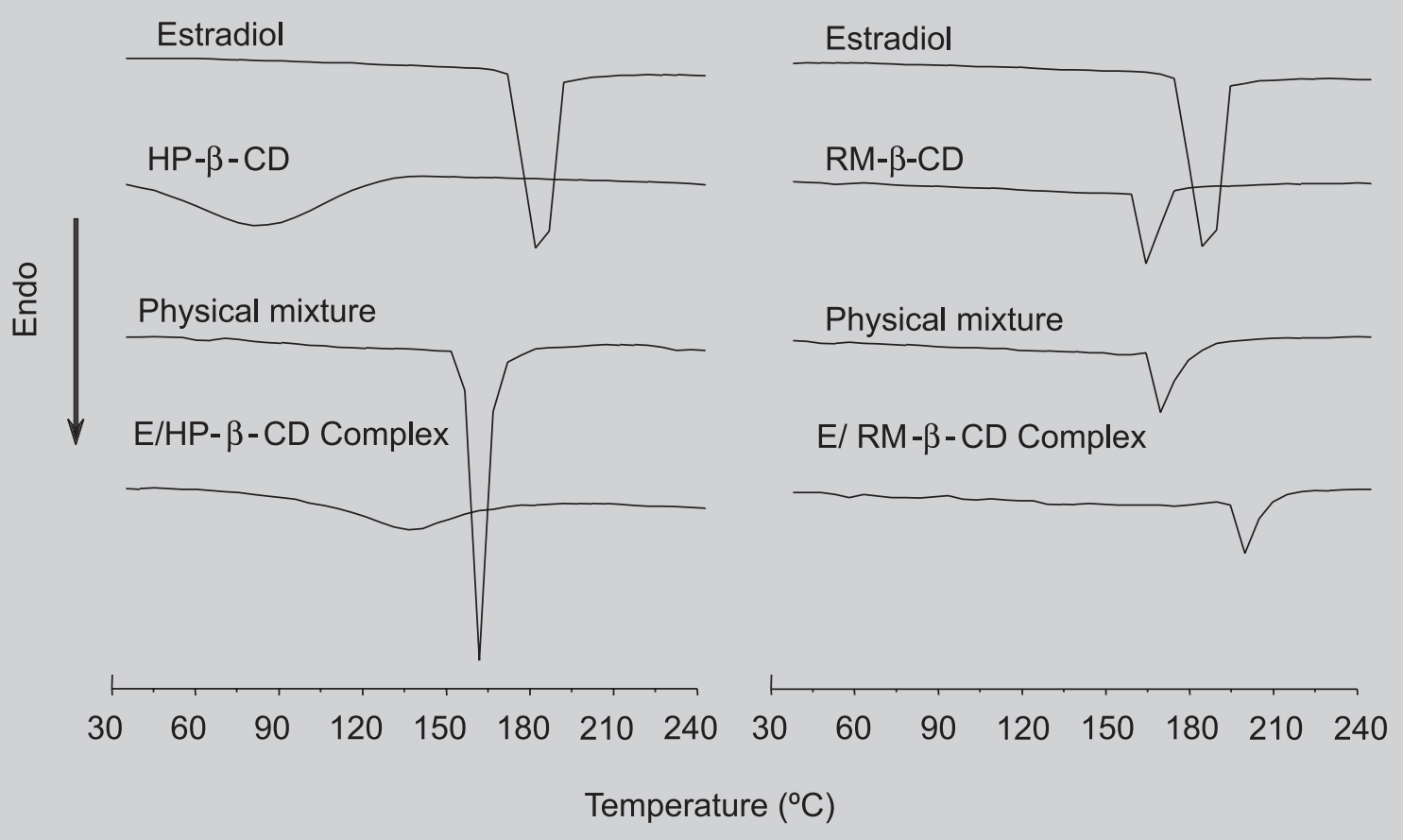

FIGURE 2 - DSC thermograms of estradiol, HP- $\beta-C D$, RM- $\beta-C D$, estradiol/CD complexes and their respective equimolar physical mixture.

TABLE I - Summary of phase solubility studies

\begin{tabular}{lccc}
\hline Complex & Solubility enhancement $^{\mathrm{a}}$ & $\mathrm{Kc}^{\mathrm{b}}$ & Molar ratio (E:CD) \\
\hline E/HP- $\beta-\mathrm{CD}$ & 110 -fold & $3060 \mathrm{M}^{-1}$ & $1: 3$ \\
E/RM- $\beta$-CD & 139 -fold & $4230 \mathrm{M}^{-1}$ & $1: 2.4$ \\
\hline
\end{tabular}

${ }^{a}$ In the presence of $50 \mathrm{mM}$ of CD. ${ }^{b}$ Apparent $1: 1$ constant stability; E/HP- $\beta-C D=$ complex of estradiol and hydroxypropylpropyl- $\beta$-cyclodextrin; $\mathrm{E} / \mathrm{RM}-\beta-\mathrm{CD}=$ complex of estradiol and methylated $-\beta$-cyclodextrin. 
very broad endothermic peak between 30 and $130{ }^{\circ} \mathrm{C}$ (maximum at $81.6^{\circ} \mathrm{C}$ ), assigned to water loss (Loftsson, Brewster, 1996). An endothermic peak at $160.6^{\circ} \mathrm{C}$ was noticed in the RM- $\beta$-CD thermogram, which may be associated with fusion (Moyano et al., 1997). In both physical mixtures, two interesting events were observed: the appearance of new endothermic transitions ( $T_{\text {peak }}=158.9^{\circ} \mathrm{C}$ and $T_{\text {peak }}=165.5^{\circ} \mathrm{C}$ for estradiol/HP- $\beta-\mathrm{CD}$ and estradiol/RM- $\beta-\mathrm{CD}$, respectively) and the complete disappearance of typical estradiol and CDs endothermic peaks. The appearance of these new transitions indicates a possible complex formation or at least an interaction between drug and CDs molecules in a solid state, that is, during the physical mixture procedure.

The thermograms of both complexes also exhibited only one endothermic peak, which was found at different temperatures of estradiol fusion peak and CDs transitions. In this way, based on DSC and solubility data, it could be hypothesized that RM- $\beta$-CD interacts more favorably with estradiol molecules forming the most stable complex, since the estradiol/RM- $\beta$-CD complex showed a new endothermic peak at a higher temperature $\left(T_{\text {peak }}=194.3^{\circ} \mathrm{C}\right)$ than the estradiol fusion peak. In contrast, a broad peak at lower temperature $\left(T_{\text {peak }}=140.3{ }^{\circ} \mathrm{C}\right)$ was noted for estradiol/HP- $\beta$-CD complex. Other authors have also reported similar transitions for methylated $\beta$-CDs and HP$\beta$-CD inclusion complexes with apolar drugs (Green, Miller, Guillory, 1991; Moyano et al., 1997; Vianna et al., 1998; Pralhad, Rajendrakumar, 2004; Mura et al., 2005). Although it was demonstrated that estradiol interacts with CDs molecules, it is not possible to determine through DSC analyses if estradiol enters the CDs cavity or interacts with the external surface of CDs. To confirm that the increase in estradiol aqueous solubility occurs due to inclusion complexation, ${ }^{1} \mathrm{H}-\mathrm{NMR}$ experiments were performed.

\section{Nuclear magnetic resonance measurements ('H-NMR)}

${ }^{1} \mathrm{H}-\mathrm{NMR}$ studies provide information on the existence of drug/CDs complexes in solution and suggest the orientation of guest molecules into the $\mathrm{CD}$ cavity. ${ }^{1} \mathrm{H}-\mathrm{NMR}$ results for RM- $\beta-C D$ and HP- $\beta-C D$ are summarized in Table II. The ${ }^{1} \mathrm{H}$-chemical shifts observed for $\mathrm{H}-3$ and $\mathrm{H}$ 5 hydrogens of RM- $\beta-C D$ and HP- $\beta-C D$, which are located in the internal surface of CDs cavity, evidenced the estradiol inclusion complexation with both CDs. Moreover, all RM$\beta$-CD hydrogens were deshielded in the presence of estradiol

TABLE II - ${ }^{1} \mathrm{H}$ chemical shifts of free CDs and in the presence of estradiol

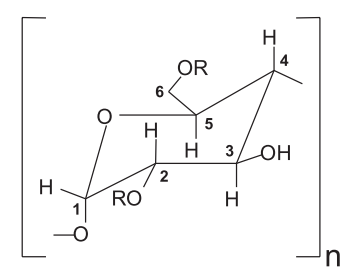

\begin{tabular}{lcccccc}
\hline Hydrogen & RM- $\beta-C D$ & $\begin{array}{c}\text { E/RM- } \beta-C D \\
\text { complex }\end{array}$ & $\Delta \delta^{*}$ & HP- $\beta-C D$ & $\begin{array}{c}\text { E/HP- } \beta-C D \\
\text { complex }\end{array}$ & $\Delta \delta^{*}$ \\
\hline H-1 & 5.115 & 5.131 & 0.02 & 5.007 & 4.979 & -0.03 \\
H-2 & - & - & - & 3.706 & 3.677 & -0.03 \\
H-3 & 3.479 & 3.525 & 0.05 & 3.573 & 3.539 & -0.03 \\
H-4 & - & - & - & 3.507 & 3.466 & -0.04 \\
H-5 & 3.753 & 3.779 & 0.03 & 3.827 & 3.784 & -0.04 \\
H-6 & 3.849 & 3.885 & 0.04 & 3.975 & 3.938 & -0.04 \\
H-7 & - & - & - & 1.133 & 1.100 & -0.03 \\
$\mathrm{H}-8$ & - & - & - & 5.145 & 5.118 & -0.03 \\
$\mathrm{CH} 3 \mathrm{O}-\mathrm{C}_{2,3}$ & 3.329 & 3.370 & 0.04 & - & - & - \\
$\mathrm{CH} 3 \mathrm{O}-\mathrm{C}_{6}$ & 3.524 & 3.573 & 0.05 & - & - & - \\
\hline
\end{tabular}

$* \Delta \delta\left(\delta_{\text {complex }}-\delta\right)$

$\mathrm{RM}-\beta-\mathrm{CD}\left(\mathrm{R}=\mathrm{CH}_{3}\right)$

$\begin{array}{lll}7 & 8 & 9\end{array}$

$\mathrm{HP}-\beta-\mathrm{CD}\left(\mathrm{R}=\mathrm{CH}_{2} \mathrm{CHOHCH}_{3}\right)$ 
molecules. This behavior can be associated with a decrease in the eletronic density around RM- $\beta-C D$ hydrogens, probably due to van der Waals forces, dipolo-dipolo interactions and/or hydrogen bounds between drug and CDs molecules (Másson et al., 1998; Ventura et al., 1998). On the other hand, the presence of estradiol molecules increased the eletronic density around HP- $\beta$-CD hydrogens, inducing low frequency shifts as shown in Table II. Similarly, other reports have also demonstrated low frequency shifts for CDs hydrogens, which are considered to be induced by the diamagnetic anisotropic effect of the aromatic moiety of guest molecules (Dollo et al., 1996; Másson et al., 1998; Ventura et al., 1998).

Table III shows the effects of HP- $\beta-C D$ and RM$\beta-C D$ on some estradiol hydrogens. The hydrogens present in the aromatic moiety were shielded in the presence of both CDs whereas $\mathrm{H}-18$ present in the methyl group was deshielded. According to Ventura et al. (1998) diamagnetic shifts of drug hydrogens could be related to interactions with CDs oxygen atoms, which are rich in free electrons. Unfortunately, a conclusion could not be defined on the way of estradiol inclusion into the CDs cavity since most estradiol hydrogens were overlapped by those of CDs in the NMR graphs.

The increase in estradiol aqueous solubility in addition to changes in its thermogram due to CDs influence, and ${ }^{1} \mathrm{H}$-chemical shifts observed for $\mathrm{H}-3$ and $\mathrm{H}-5$ hydrogens located in the internal surface of CDs cavity due to the presence of estradiol molecules, suggest that estradiol forms inclusion complexes with both RM- $\beta-\mathrm{CD}$ and HP$\beta-C D$. Moreover, the data found are corroborated by literature (Albers, Muller, 1992).

\section{Skin permeation/retention studies}

Permeation profiles of estradiol in the free state and complexed with RM- $\beta-C D$ and HP- $\beta-C D$ are displayed by Figure $3 \mathrm{~A}$. The complexation with both $\mathrm{CDs}$ significantly increased estradiol flux through the skin $(\mathrm{P}<0.01)$. The enhancement on estradiol permeability by CDs complexation was about 2-fold when compared with free estradiol. Figure 3B shows the retention profile of estradiol in the SC and tape stripped skin. The amount of estradiol retained in the SC when complexed with HP- $\beta$ $C D$ was greater than when complexed with RM- $\beta-C D$ or in free state $(\mathrm{P}<0.001)$. No statistical difference was observed in the amount of estradiol retained in the tapestripped skin (epidermis + dermis without stratum corneum).

It has been demonstrated that some modified $\beta$-CDs such as methylated $\beta$-CDs and hydroxypropyl$\beta-\mathrm{CD}$ (HP- $\beta-\mathrm{CD})$ are capable of extracting lipids from $\mathrm{SC}$ and therefore reducing the skin barrier, acting as true absorption enhancers (Vollmer et al., 1994; Bentley et al., 1997; Másson et al., 1999; Lopez, Collett, Bentley, 2000; Babu, Pandit, 2004). In order to verify the influence of CDs on the SC barrier, pretreatment studies were performed by treating the skin with aqueous solutions containing $20 \%(\mathrm{w} / \mathrm{v})$ of RM- $\beta$-CD or HP- $\beta$ $\mathrm{CD}$ during $4 \mathrm{~h}$ before carrying out permeation experiments with saturated solutions of estradiol. Vollmer et al. (1994) have demonstrated that in this condition, the absorption of the cytochrome P450 inhibitor liarozole increased almost 10 fold in a rat model. However, as shown in Figure 4A, RM- $\beta$-CD pretreatment exhibited a slight enhancement in the

TABLE III - ${ }^{1} \mathrm{H}$ chemical shifts of estradiol in the free state and in the presence of CDs

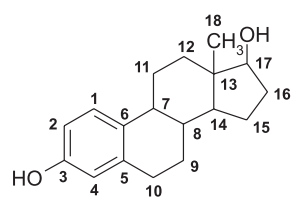

\begin{tabular}{lccccc}
\hline Hydrogen & Estradiol & E/HP- $\beta$-CD complex & $\Delta \delta^{*}$ & E/RM- $\beta$-CD complex & $\Delta \delta^{*}$ \\
\hline H-1 & 7.170 & 7.134 & -0.04 & 7.132 & -0.04 \\
H-2 & 6.628 & 6.514 & -0.01 & 6.582 & -0.05 \\
H-4 & 6.582 & 6.482 & -0.02 & 6.521 & -0.06 \\
H-17 & 3.699 & - & - & - & - \\
H-18 & 0.763 & 0.793 & 0.03 & 0.780 & 0.02 \\
\hline
\end{tabular}

$* \Delta \delta\left(\delta_{\text {complex }}-\delta\right)$ 
estradiol flux when compared with the control group, but no statistical difference was found. The retention experiments performed after pretreatments are illustrated in Figure 4B. RM- $\beta$-CD significantly increased the retention of estradiol in $\mathrm{SC}(\mathrm{P}<0.01)$, but no statistical difference was observed between CDs and control group on the amount of estradiol retained in the tape-stripped skin.

The results obtained from retention studies indicate that HP- $\beta-C D$ and RM- $\beta-C D$ are able to modify the partitioning of estradiol into SC, but in different ways. While complexation with HP- $\beta-C D$ enhanced the amount of estradiol retained in SC, only the RM- $\beta$-CD pretreatment increased hormone retention. It could be

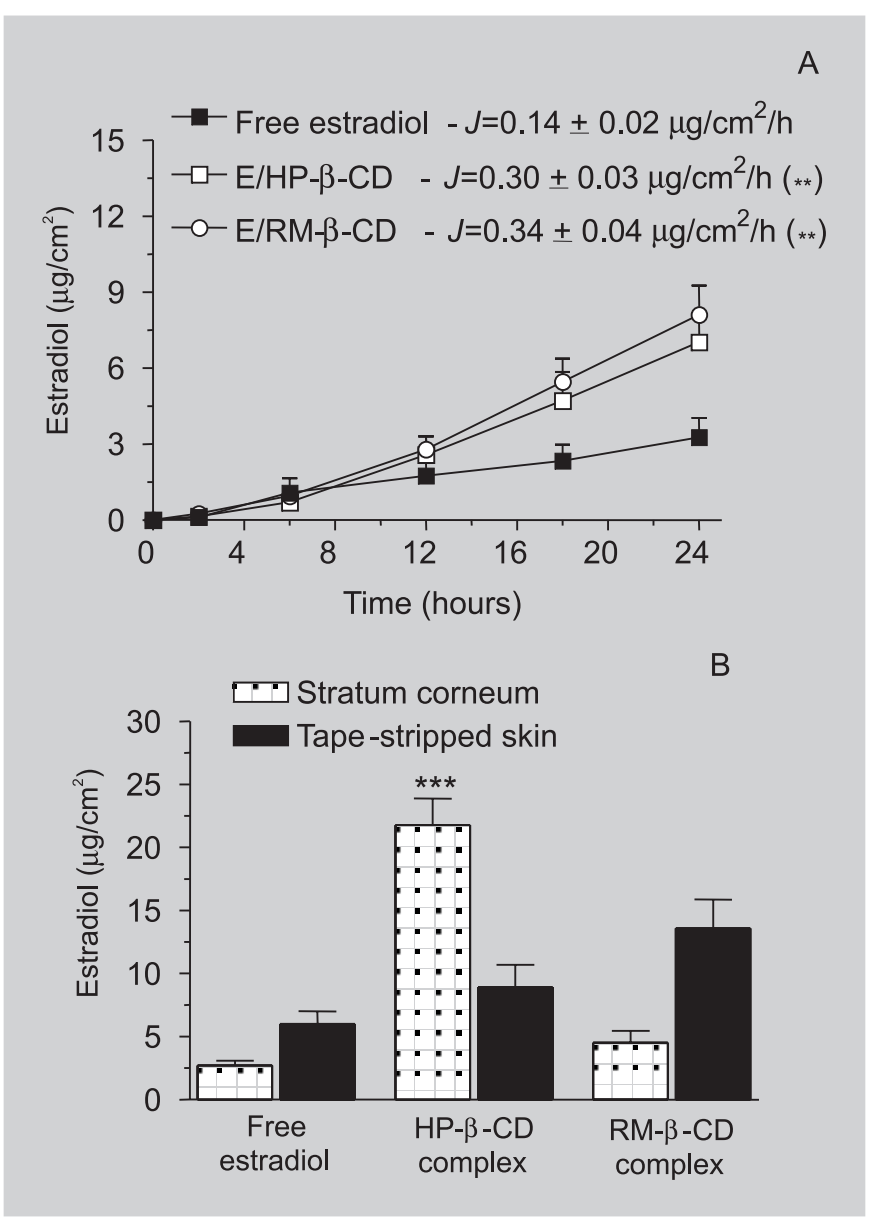

FIGURE 3 - (A) Permeation profiles of estradiol in the free state (control group) and complexed with HP- $\beta-C D$ and RM- $\beta$-CD through hairless mouse skin. (B) Total amount of estradiol retained in the stratum corneum (SC) and in the tape-stripped skin (epidermis + dermis without SC) after $24 \mathrm{~h} . * * *$ indicates significant difference $(\mathrm{P}<0.01$ and $\mathrm{P}<0.001$, respectively) between estradiol in the free state and complexed with CDs. Values are expressed as means $\pm \mathrm{SEM}, \mathrm{n}=6$ for each group. associated with different degrees of interaction of these CDs with skin components. Some authors have shown that lipophilic CDs such as methylated $\beta-\mathrm{CD}$ interact better with the skin and are able to extract lipid components from SC (Vollmer et al., 1994; Loftsson, Másson, 2001) whereas hydrophilic CDs interact in a lower extent with the skin, as noted for HP- $\beta-C D$ (Bentley et al., 1997; Matsuda, Arima, 1999). Nevertheless, there are few reports about the influence of CDs on drug retention in the skin layers, and more studies are necessary to elucidate their mechanism of action.
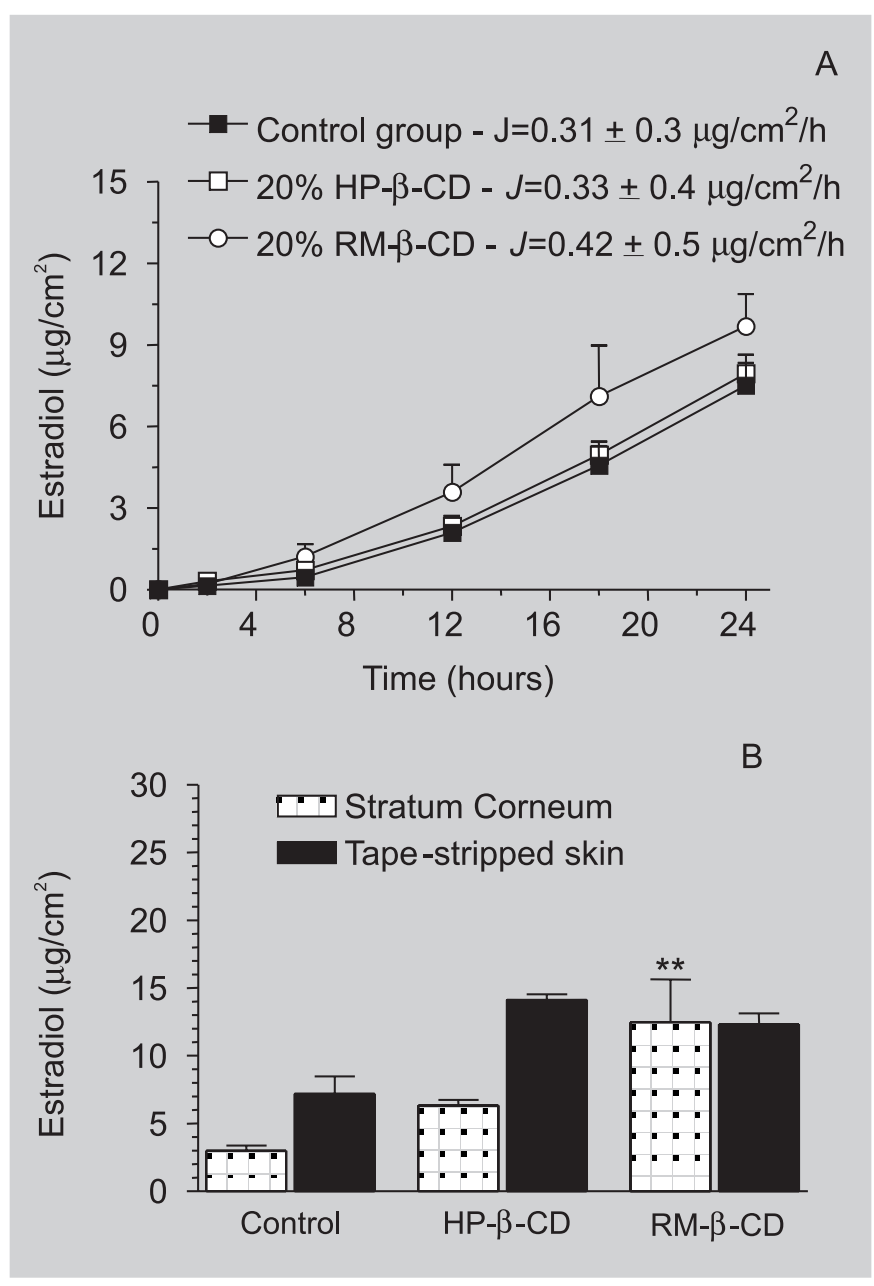

FIGURE 4 - (A) Permeation profiles of estradiol after skin pretreatment with aqueous solution (control group) containing $20 \%(\mathrm{w} / \mathrm{v})$ of HP- $\beta$-CD or RM- $\beta$-CD during $4 \mathrm{~h}$ prior to the permeation experiment with estradiol saturated solution in PG:water $(1: 1 ; \mathrm{v} / \mathrm{v})$. (B) Total amount of estradiol retained in the stratum corneum (SC) and in the tape-stripped skin (epidermis + dermis without $\mathrm{SC}$ ) after $24 \mathrm{~h} .{ }^{* *}$ Indicates significant difference $(\mathrm{P}<0.01)$ between control group and RM- $\beta-C D$ pretreatment. Values are expressed as means \pm SEM, $\mathrm{n}=4$ for each group. 
Additionally, it has been demonstrated that depending on the vehicle composition, CDs can either increase or decrease drug flux through the skin. For example, in hydrophilic ointments, HP- $\beta-C D$ increased the flux of ethyl 4-biphenylyl acetate through hairless mouse skin, but decreased the flux from non-aqueous PG based vehicle (Arima et al., 1998). Some reports also showed that excess of $C D$, i.e. more than the amount necessary to solubilize a lipophilic drug in an aqueous medium, generally decreases drug penetration through the skin (Másson et al., 1999; Loftsson, Másson, 2001). However, Babu and Pandit (2004) noticed a higher effect for a methylated $\beta-\mathrm{CD}$ on the permeability of bupranolol through rat skin than HP- $\beta$ $\mathrm{CD}$, which was associated with the combined effect of enhancing aqueous solubility of bupranolol and reducing barrier function of the skin by methylated $\beta-C D$.

Although RM- $\beta$-CD may be able to enhance drug flux through the skin by extracting lipid components from $\mathrm{SC}$, the results obtained in this study suggest that the enhancing effect of HP- $\beta-C D$ and RM- $\beta-C D$ on estradiol skin permeation can be mainly described as an increase in drug availability on the skin surface due to the inclusion complexation. Furthermore, the formation of a significant reservoir of estradiol in the SC due to the HP- $\beta$-CD complexation makes it an interesting approach to hormone replacement therapy by the transdermal route.

\section{ACKNOWLEDGEMENTS}

The authors thank FAPESP (Fundação de Amparo à Pesquisa do Estado de São Paulo), Brazil, for supporting this study.

\section{RESUMO}

\section{Efeito promotor de beta-ciclodextrinas modifica- das na permeação in vitro do estradiol}

Estradiol, o mais importante hormônio feminino, foi complexado com hidroxipropil- $\beta$-ciclodextrina (HP- $\beta$ $C D)$ e metil- $\beta$-ciclodextrina randômica (RM- $\beta-C D)$. Após a obtenção dos complexos, os mesmos foram caracterizados por estudos de solubilidade, CDV e RMN$H^{1}$. O efeito das CDs sobre a absorção/retenção do estradiol na pele foi investigado in vitro em células de difusão de Franz. As CDs aumentaram a solubilidade aquosa do estradiol em diferentes proporções. As análises de CVD e RMN-H $H^{1}$ comprovaram a complexação do estradiol com ambas $C D$ s, sendo que RM- $\beta-C D$ apresentou interação mais forte com estradiol do que HP- $\beta$-CD. Mais adiante, a formação de complexos aumentou o fluxo de estradiol através da pele $(P<0,01)$, mas o aumento de fármaco no estrato córneo (EC) foi observado somente após complexação com HP- $\beta-C D$. Por outro lado, somente a RM- $\beta-C D$ foi capaz de aumentar a retenção do fármaco no EC após o pré-tratamento da pele com CDs. Os resultados sugerem que o efeito promotor das CDs no fluxo de estradiol pode ser descrito principalmente como aumento da disponibilidade de fármaco na superfície da pele devido à complexação. Além disso, a formação de um significativo reservatório do hormônio no EC torna a complexação com HP- $\beta$-CD uma estratégia interessante para liberação transdérmica do estradiol.

UNITERMOS: Estradiol. Hidroxipropil- $\beta$-ciclodextrina. Metil- $\beta$-ciclodextrina randômica. Complexo de inclusão. Permeação cutânea. Promotor de absorção.

\section{REFERENCES}

ALBERS E, MULLER BW. Complexation of steroid hormones with cyclodextrin derivatives: substituent effects of the guest molecule on solubility and stability in aqueous solution. J. Pharm. Sci., New York, v.81, p.756-761, 1992.

ARIMA, H.; MIYAJI, T.; IRIE, T.; HIRAYAMA, F.; UEKAMA, K. Enhancing effect of hydroxypropyl-bcyclodextrin on cutaneous penetration and activation of ethyl 4-biphenylyl acetate in hairless mouse skin. Eur. $J$. Pharm. Sci., Amsterdam, v.6, p.53-59, 1998.

BABU, R.J.; PANDIT, J.K. Effect of cyclodextrins on the complexation and transdermal delivery of bupranolol through rat skin. Int. J. Pharm., Amsterdam, v.271, p.155-165, 2004.

BENTLEY, M.V.L.B.; VIANNA, R.F.; WILSON, S.; COLLETT, J.H. Characterization of the influence of some cyclodextrins on the stratum corneum from the hairless mouse. J. Pharm. Pharmacol., London, v.49, p.397-402, 1997.

DEL VALLE, E.M.M. Cyclodetrins and their uses: a review. Process Biochem., London, v.39, p.1033-1046, 2004.

DOLLO, G.; LE CORRE, P.; CHEVANNE, F.; LE VERGE, R. Inclusion complexation of amide-typed local anaesthetics with $\beta$-cyclodextrin and its derivatives. I. Physicochemical characterization. Int. J. Pharm., Amsterdam, v.131, p.219-228, 1996. 
ESSA, E.A.; BONNER,M.C.; BARRY, B.W. Electrically assisted skin delivery of liposomal estradiol; phospholipid as damage retardant. J. Control. Rel., Amsterdam, v.95, p.535-546, 2004.

GREEN, A.R.; MILLER, E.S.; GUILLORY, J.K. Physical properties of the complexes formed between heptakis (2, 6-di-O-methyl)-b-cyclodextrin, b-cyclodextrin, and chlorambucil.J. Pharm. Sci., Easton, v.80, p.186-189, 1991.

HADGRAFT, J. Skin deep. Eur. J. Pharm. Biopharm., Amsterdam, v.58, p.291-299, 2004.

HIGUCHI, T. and CONNORS, K.A. Phase solubility techniques. Adv. Anal. Chem. Instr., New York, v.4, p.117-212, 1965.

KENEMANS, P.; VAN UNNIK, G.A.; MIJATOVIC, V.; VAN DER MOOREN, M.J. Perspectives in hormone replacement therapy. Maturitas, Ireland, v.38, Suppl, S41S48, 2001.

LOFTSSON, T.; BREWSTER, M.E. Pharmaceutical applications of cyclodextrins. 1. Drug solubilization and stabilization. J. Pharm. Sci., Easton, v.85, p.1017-1025, 1996.

LOFTSSON, T.; HREINSDÓTTIR, D.; MÁSSON, M. Evaluation of cyclodextrin solubilization of drugs. Int. J. Pharm., Amsterdam, v.302, p.18-28, 2005.

LOFTSSON, T.; MÁSSON, M. Cyclodextrins in topical drug formulations: theory and practice. Int. J. Pharm., Amsterdam, v.225, p.15-30, 2001.

LOPEZ, R.F.V.; COLLETT, J.H.; BENTLEY, M.V.L.B. Influence of cyclodextrin complexation on the in vitro permeation and skin metabolism of dexamethasone. Int. J. Pharm., Amsterdam, v.200, p. 127-132, 2000.

MÁSSON, M.; LOFTSSON, T.; JÓNSDÓTTIR, S.; FRIDRIKSDÓTTIR, H.; PETERSEN, D.S. Stabilization of ionic drugs through complexation with non-ionic and ionic cyclodextrins. Int. J. Pharm., Amsterdam, v.164, p.45-55, 1998 .

MÁSSON, M.; LOFTSSON, T.; MÁSSON, G.; STEFÁNSSON, E. Cyclodextrins as permeation enhancers: some theoretical evaluations and in vitro testing. J. Control. Rel., Amsterdam, v.59, p.107-118, 1999.
MATSUDA, H.; ARIMA, H. Cyclodextrins in transdermal and rectal delivery. Adv. Drug Deliv. Rev., Amsterdam, v.36, p.81-99, 1999.

MILLER, M.M.; FRANKLIN, K.J.B. Theoretical basis for the benefit of postmenopausal estrogen substitution. Exp. Gerontol., London, v.34, p.587-604, 1999.

MOYANO, J.R.; ARIAS-BLANCO, M.J.; GINÉS, J.M.; GIORDANO, F. Study of the complexation behaviour of gliclazide with partially methylated b-cyclodextrin in solution and solid state. Int.J. Pharm., Amsterdam, v.157, p.239-243, 1997.

MURA, P.; FURLANETTO, S.; CIRRI, M.; MAESTRELLI, F.; CORTI, G; PINZAUTI, S. Interaction of naproxen with ionic cyclodextrins in aqueous solution and in the solid state. J. Pharm. Biomed. Anal., London, v.37, p.987-994, 2005.

PRALHAD, T.; RAJENDRAKUMAR, K. Study of freezedried quercetin-cyclodextrin binary systems by DSC, FTIR, X-ray diffraction and SEM analysis. J. Pharm. Biomed. Anal., London, v.34, p.333-339, 2004.

PRAUSNITZ, M.R.; MITRAGOTRI, S.; LANGER, R. Current status and future potential of transdermal drug delivery. Nat. Rev. Drug. Discov., London, v.3, p.115-124, 2004.

RUSSELL, J.A.; MALCOLM, R.K.; CAMPBELL, K.; WOOLFSON, A.D. High-performance liquid chromatographic determination of 17beta-estradiol and 17beta-estradiol-3-acetate solubilities and diffusion coefficents in silicone elastromeric intravaginal rings. $J$. Chromatogr. B., Amsterdam, v.744, p.157-163, 2000.

STELLA, V.J.; RAO, V.M.; ZANNOU, E.A.; ZIA, V. Mechanisms of drug release from cyclodextrin complexes. Adv. Drug Deliv. Rev., Amsterdam, v.36, p.3-16, 1999.

SURBER, C.; SCHWARB, F.P.; SMITH, E.W. in: BRONAUGH, R.L.; MAIBACH, H.I. (Eds.), Percutaneous absorption: Drugs-cosmeticsmechanisms-methodology, New York: Marcel Dekker, 1999. p. 395-410.

VENTURA, C.A.; PUGLISI, G.; ZAPPALÀ, M.; MAZZONE, G. A physico-chemical study on the interaction between papaverine and natural and modified $\beta$-cyclodextrins. Int. J. Pharm., Amsterdam, v.160, p.163-172, 1998. 
VIANNA, R.F.L.; BENTLEY, M.V.L.B.; RIBEIRO, G.; CARVALHO, F.S.; NETO, A.F.; OLIVEIRA, D.C.R.; COLLETT, J.H. Formation of cyclodextrin inclusion complexes with corticosteroids: their characterization and stability. Int. J. Pharm., Amsterdam, v.167, p.205-213, 1998.

VOLLMER, U.; MÜLLER, B.M.; PEETERS, J.; MESENS, J.; WILFFERT, B.; PETERS, T. A study of the percutaneous absorption-enhancing effects of cyclodextrin derivatives in rats. J. Pharm. Pharmacol., London, v.46, p.19-22, 1994.
WARMING, L.; RAVN, P.; CHRISTIANSEN, C. Levonorgestrel and 17-beta-estradiol given trandermally for the prevention of postmenopausal osteoporosis. Maturitas, Ireland, v.50, p.78-85, 2005.

WILLIAMS, A.C.; BARRY, B.W. Penetration Anhancers. Adv. Drug Deliv. Rev., Amsterdam, v.56, p.603-618, 2004.

Recebido para publicação em 25 de novembro de 2005. Aceito para publicação em 19 de setembro de 2006. 